\title{
Effect of Pasteurization Temperature on the Quality of Goat Cheese
}

\author{
SMITA GURUNG ${ }^{1}$ and BAIDYA NATH PRASAD SAH ${ }^{2 *}$
}

\author{
${ }^{1}$ Lalitpur Valley College, Lalitpur \\ ${ }^{2}$ Dairy Development Corporation, Kathmandu, Nepal
}

The research was carried to study quality and yield of goat cheese by varying pasteurisation conditions; $63^{\circ} \mathrm{C}$ for $30 \mathrm{~min}($ Sample A), $80^{\circ} \mathrm{C}$ for $10 \mathrm{~min}$ (Sample B) and $90^{\circ} \mathrm{C}$ for $60 \mathrm{sec}$ (Sample C). Titrable acidity, pH, moisture, fat, protein and ash, total plate count, Coliform count of goat milk, cheese samples $A, B$, and $C$ were measured. There were fat recoveries of $67.23 \%$, $67.72 \%$, and $70.15 \%$ while protein recoveries of $71.15 \%, 66.88$, and 69.32 respectively in the samples $A$, B, and $C$. The samples $A$, B, and $C$ had moisture content of $59.72 \%, 63.15 \%$, and $64.3 \%$. The samples were subjected to sensory evaluation in term of color, flavor, texture, taste and overall acceptability on a 9-point hedonic rating scale. The data obtained were analysed statistically $(p<0.05)$. Sample $C$ was ranked the best.

Keywords: Goat milk, Goat cheese, Whey, Rennet, Pasteurisation

\section{Introduction}

Cheese is nutritious food made mostly from the milk of cows but also from other mammals including sheep, goat, buffalo, reindeer, camel and yaks (De, 2004). However, the use of goat milk to make goat cheese is based on two reasons- nutritional value and taste that contribute to the popularity of goat cheese. Goat cheese is a cheese made from goat milk rather than either sheep or cows milk and is known for their peculiar white colour and flavour. The production of cheese from goat milk has a very long history. In Homer's Odyssey, there is a very vivid description of the manufacture of cheese by the beastly Cyclops, Polyphemos, perhaps the oldest recorded cheese- maker in the world. The Cyclops, who enjoyed mythical strength from the milk and the cheese of goats, is a bucolic symbol, which exists even now in some Mediterranean countries (Fox, 1987).

Goat cheese contains $40-45 \%$ fat which is similar to a good cheddar cheese (48\%), but lower than sheep/cows cheese (up to $70 \%$ ). There is not great differences in proportion of goat milk with cow or sheep milk but there is biggest difference in high proportion of fatty acid composition especially capric, caprylic and caproic acids. This fatty acid composition gives the milk and resulting goat cheeses their unique tangy flavour (Kosikowoski and Mistry, 1995). The strength of the taste can be changed due to the hormonal influence of the female goat. When goat milk is aged the tangy flavour gives away to creamy and earthy flavour, which is the characteristic of goat cheese. The flavour of the cheese depends not only on the breed, feed but also on the method of cheese production, period of ripening and many other factors. Goat cheese is popular for its sharp and exciting flavour. Protein found in goat cheese is twice as much as that in cow cheese. In addition, goat cheese has fewer calories and provides less cholesterol and fat. Owing to its high digestibility, people usually prefer goat cheese to other cheeses. Overall total solids of goat milk is the strongest indicator of yield in all three types of cheeses, followed by the fat, total protein, where as casein is not good predictor for both semi-solid and hard cheese (Upadhaya, 2003).

\footnotetext{
*Corresponding author, E-mail: baidyasah@yahoo.com
}

French legislation defines and protects the designation 'goats' and 'semi-goats' cheeses. Thus designations 'goat's cheese' or 'goat blue cheese' may be used only for cheeses of various shapes and weights made solely from goats' milk. In other countries, a number of cheeses are made mainly from goat milk, but sometimes with the addition of sheep and/or cow milk. Most are fresh or ripened only for a short period and rarely are smoked, e.g. Palmero and Majerero from the Canary Island. Surface mould-ripened soft cheeses, with Penicillium candidum, are Sainte Maure, Grottin from France and Altenburg from Germany. Blue type cheese with Penicillium glaucum, are Cabrales from Spain and Gemonedo from Portugal.

Mostly goat cheese in Nepal is imported from France and Italy. Nepal has started its production from last few years in Chitlang VDC in Makwanpur district, which is the first goat cheese factory in Nepal. There are 88 farmers being confined within this factory and it has been supplying small quantity cheese (about 2-3 kg per day) in 5-star hotel. Due to its rareness and high price it is not reachable to all kinds of people. It becomes necessity to upgrade and scale up of such high valued goat cheese. Therefore, the general objective is to vary pasteurisation conditions for yields increment; and the specific objectives are to optimise the pasteurisation conditions of making fresh soft goat cheese and to evaluate compositional characteristics and yields.

\section{Materials and Methods}

Raw materials- About 20 litres of fresh goat milk $\left(26^{\circ} \mathrm{C}\right)$ was collected from the local people and it was mixed thoroughly. The milk had lactometer reading of 28.3 corresponding of SNF $8.95 \%$ (KC and Rai, 2007). Milk showed negative test on both COB test and alcohol test ( $68 \%$ ethanol). The preparation of cheese was done in Chitlang Cheese Factory, Makwanpur. Starter culture and rennet powder of CHR. HANSEN was purchased. 3 to $4 \mathrm{ml}$ refrigerated rennet solution was mixed in warm water for the preparation of rennet solution. 3-4 ml of rennet solution coagulates 5 litres of milk at $35^{\circ} \mathrm{C}$ in 40 minutes (DDC, 2005). 
Procedure- The methodology of goat cheese production process was done according to Kalantzopoulos, (1993) and Pradhan (2000) with little modification as mentioned in Figure 1. This process was running in Chitlang Goat Cheese Factory as information given by Ashok Singh Thakuri (Makwanpur, Chitlang VDC).

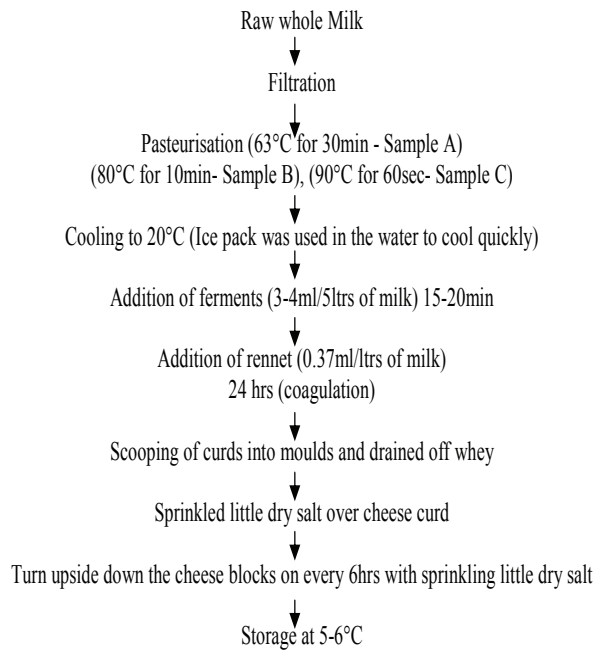

Figure 1. Flow-chart for the preparation of soft cheese from goat milk at various pasteurisation conditions

Figure 1. Flow-chart for the preparation of soft cheese from goat milk at various pasteurisation conditions

Sensory evaluation- Fresh goat cheese samples were evaluated by a selected panel of 9 judges on a 9-point hedonic rating scale for colour, texture, aroma, taste and overall acceptability according to Ranganna (2000).

Statistical analysis- The experiment was conducted in triplicate. The data were statistically analyzed by using Genstat programming (Genstat version 5) at 5\% level of significance. The means were compared using LSD and the best treatment was selected.

Results and Discussion

The compositional characteristic of goat milk which was used for the preparation of soft cheese is summarized in Table 1. Different pasteurization temperature and time were used to manufacture fresh soft cheese from whole goat milk.

Table 1. Compositional characteristics of goat milk used for manufacturing soft cheese

\begin{tabular}{lc}
\hline Parameters & Mean (S.D) \\
\hline $\mathrm{pH}$ & $6.6(0.32)$ \\
Titrable acidity $(\%)$ & $0.18(0.01)$ \\
Moisture content $(\%)$ & $87.25(0.14)$ \\
Fat $(\%)$ & $6.00(0.43)$ \\
Protein (\%) & $4.16(0.20)$ \\
Ash $(\%)$ & $0.86(0.01)$ \\
\hline
\end{tabular}

The chemical composition of soft cheeses made from goat milk obtained by using different pasteurisation conditions has been shown in Table 2. The moisture content in all sample A, B and C of cheeses were found by 59.72, 63.15 and 64.83 where as protein was found $14.8,12.58$ and $12.4 \%$ respectively. It was found that moisture content in sample $\mathrm{C}$ has the highest value, sample B has higher and sample A has the least value. Similarly, sample A has highest, B has higher and sample $\mathrm{C}$ has least value in protein and fat content in lab prepared cheese. Hence it can be conclude that increase in pasteurization temperature resulted in significant increases in moisture content and reduction in fat and protein content. Similar observations have been reported previously (Guinee, et al., 1998). The positive relationship between pasteurization temperature and cheese moisture showed an adverse effect of heat treatment on syneresis of rennet-induced milk gels in model systems. The adverse effects of HPT on syneresis are probably due, in part, to the presence of denatured whey protein- $\kappa$-casein complexes on the surface of the rennet-treated micelles that retard aggregation and fusion of the rennettreated micelles. The decrease in levels of protein and fat with pasteurization temperature are due to concomitant increase in moisture, and hence reduce in level of cheese dry matter.

Table 2. Chemical composition of soft goat cheese from the milk of different degree of pasteurization temperature and time

\begin{tabular}{llll}
\hline Cheese Sample & Sample 'A' & Sample 'B' & Sample 'C' \\
\hline $\mathrm{pH}$ & $6.35(0.18)^{\mathrm{a}}$ & $5.74(0.20)^{\mathrm{b}}$ & $5.46(0.05)^{\mathrm{b}}$ \\
Titrable acidity (\%) & $0.31(0.10)^{\mathrm{a}}$ & $0.44(0.04)^{\mathrm{a}}$ & $0.42(0.03)^{\mathrm{a}}$ \\
Moisture (\%) & $59.72(0.68)^{\mathrm{a}}$ & $63.15(0.74)^{\mathrm{b}}$ & $64.3(0.15)^{\mathrm{b}}$ \\
Fat (\%) & $20.17(0.29)^{\mathrm{a}}$ & $18.60(0.20)^{\mathrm{b}}$ & $18.10(0.10)^{\mathrm{b}}$ \\
Protein (\%) & $14.82(0.20)^{\mathrm{a}}$ & $12.53(0.45)^{\mathrm{b}}$ & $12.4(0.50)^{\mathrm{c}}$ \\
Salt (\%) & $1.43(0.08)^{\mathrm{a}}$ & $1.84(0.14)^{\mathrm{b}}$ & $1.87(0.03)^{\mathrm{b}}$ \\
Ash (\%) & $4.17(0.25)^{\mathrm{a}}$ & $3.21(0.26)^{\mathrm{b}}$ & $3.10(0.11)^{\mathrm{b}}$ \\
\hline
\end{tabular}

Note: Values in the column bearing similar superscript are not significantly different at $5 \%$ level of significance.

In agreement with an earlier study (Guinee et al., 1998), increasing pasteurization temperature of the milk significantly reduced the $\mathrm{pH}$ of the cheese at 1 day; this trend continued throughout ripening with a significant effect of pasteurization temperature on the mean $\mathrm{pH}$ over the ripening period. The lower $\mathrm{pH}$ in the HPT cheeses is due to their higher level of moisture and, thus, lactic acid (Wallace and Fox, 1997Walstra, P., Noomen, A. and Geurts, T.J., 1993. Dutch-type varieties. In: Fox, P.F., Editor, , 1993. Cheese: Chemistry, physics and microbiology, vol. 2, major cheese groups (2nd ed.), Chapman 
\& Hall, London, pp. 39-82.) and the lower levels of protein, casein as a percentage of the total protein, and thus buffering capacity (Lucey, 1993).

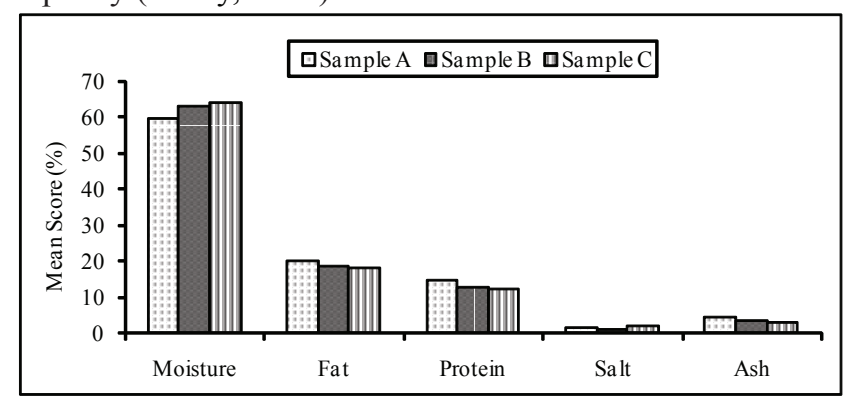

Figure 2. The chemical composition of goat cheese at different pasteurization conditions

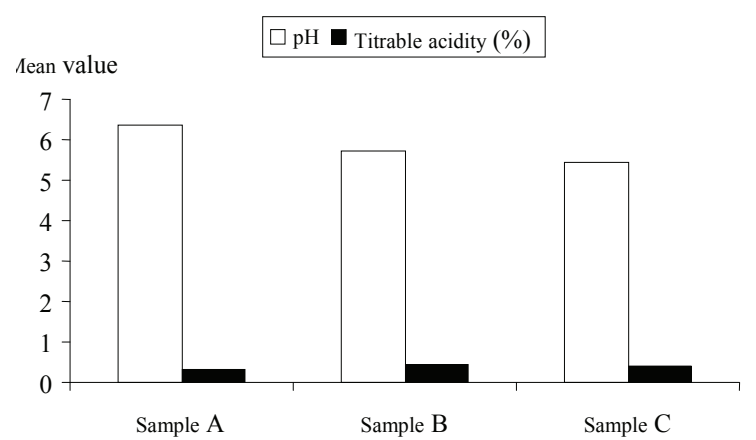

Figure 3. Mean titrable acidity (\%) and $\mathrm{pH}$ of cheese at different pasteurization temperature

Cheese yield is one of the most economically important aspects of cheese manufacturing. Abou-Donia (1896) reported that factors such as a milk composition, addition of salt, pasteurization of milk, milk concentration and addition of starter affect the yield of cheese.

Table 3. Mean yield and recovery of fat and protein from goat cheese

\begin{tabular}{cccc}
\hline \multirow{4}{*}{ Cheese sample } & Mean yield & Fat & Protein \\
\hline A & $19.96(0.78)^{\mathrm{a}}$ & $67.23(1.07)^{\mathrm{a}}$ & $71.15(0.97)^{\mathrm{c}}$ \\
B & $22.22(0.28)^{\mathrm{b}}$ & $67.72(0.74)^{\mathrm{a}}$ & $66.88(0.50)^{\mathrm{b}}$ \\
C & $23.25(0.45)^{\mathrm{c}}$ & $70.15(0.48)^{\mathrm{b}}$ & $69.32(0.36)^{\mathrm{c}}$ \\
\hline
\end{tabular}

Note: Values are the means of three determinations. Figures in the parenthesis are the standard deviation. Values in the column bearing similar superscript are not significantly different at $5 \%$ level of significance.

Losses of milk fat and protein in cheese whey affect cheese yields markedly. Nutrient recovery (\%) is a measure of nutrient in milk retained in cheese. It is calculated as amount of nutrient in milk minus amount of nutrient in whey / amount of nutrient in milk $\times 100 \%$. Fat recovery was similar in sample $\mathrm{A}$ and $\mathrm{B}$, averaging $67.23 \%$ in $\mathrm{A}$ and $67.72 \%$ in sample $\mathrm{B}$ whereas in sample $\mathrm{C}$ it was higher averaging 70.15. The fat recovery of goat milk cheeses in this study was lower than those of industrial scale cow's milk cheeses ranging from 85 to $91 \%$ (Phelan, 1981). This observation might be resulted from smaller fat globules in goat milk. Protein recovery is also lower than those reported for cow milk cheese (74-77\%) (Callanan, 1991).

Statistically, there was significantly difference $(p<0.05)$ in mean yield of goat cheese in all three samples A, B and C. It implies that the pasteurization temperature and holding time in that temperature greatly affect the mean yield. In fat recovery in goat cheese there was no significantly difference $(p>0.05)$ of sample A and B; but sample $\mathrm{C}$ was significantly difference $(p<0.05)$. Likewise, sample A and $C$ was not significantly difference $(p>0.05)$ in protein recovery but sample B was significantly difference $(\mathrm{p}<0.05)$.

The result of the microbiological analysis of the soft cheese is presented in the Table 4. Coliforms were not detected in all the cheese samples. According to Kosikowski and Mistry, (1997) low heat treatment at 57.2, 58.9, 60, and $61.1^{\circ} \mathrm{C}$ for 16.5 seconds reduced the coliform count by $57.3,75.0,81.5$ and $93.8 \%$, respectively.

Table 4. Microbiological analysis of goat cheese

\begin{tabular}{ccc}
\hline Sample & Coliform $(\mathbf{c f u} / \mathbf{g})$ & TPC $(\mathbf{c f u} / \mathbf{g})$ \\
\hline A & ND & 395 \\
B & ND & 371 \\
C & ND & 321 \\
\hline
\end{tabular}

Note: Average value for TPC of sample A, B and C of soft cheese from goat milk.

The result from the coliform count was found that the pasteurization temperature and holding time for cheese preparation was sufficient to inactivate coliform present in milk and there was no post-contamination during cheese preparation, storage and handling. Even the culture propagation for bulk culture preparation was not found contamination. Similarly, the total count of microorganism was not so high. So, the overall microbiological quality of goat cheese was found satisfactory.

Mean scores of the sensory panels for cheese made from goats milk using different pasteurization temperature, are listed in Table 5 and in Figure 4. Statistical treatment of the data has also been shown in the same Table. These data shows that appearance, flavour, texture and overall acceptability of cheeses were affected by manufacturing process as well heating temperature of milk.

The statistical analysis shows that the colour, texture, flavour and taste characteristics are significantly different $(\mathrm{p}<0.05)$. Overall acceptability was not significantly affected $(p<0.05)$ by differentiating pasteurization temperature of milk. 
Table 5. Mean Score of sensory attributes of goat cheese

\begin{tabular}{llllll}
\hline $\begin{array}{l}\text { Cheese } \\
\text { varieties }\end{array}$ & Colour & Texture & Flavour & Taste & $\begin{array}{l}\text { Over all } \\
\text { acceptability }\end{array}$ \\
\hline Sample 'A' & $7.00(0.86)^{\mathrm{a}}$ & $7.33(1.22)^{\mathrm{a}}$ & $6.11(1.05)^{\mathrm{a}}$ & $5.77(0.97)^{\mathrm{a}}$ & $6.88(1.05)^{\mathrm{a}}$ \\
Sample 'B' $^{\text {Sample 'C' }}$ & $7.77(1.09)^{\mathrm{b}}$ & $6.88(1.16)^{\mathrm{b}}$ & $6.33(1.22)^{\mathrm{a}}$ & $7.66(1.00)^{\mathrm{b}}$ & $7.11(1.05)^{\mathrm{a}}$ \\
\hline LSD & $8.33(0.70)^{\mathrm{b}}$ & $6.33(1.32)^{\mathrm{c}}$ & $7.11(1.26)^{\mathrm{b}}$ & $6.55(0.88)^{\mathrm{a}}$ & $7.44(0.72)^{\mathrm{a}}$ \\
\hline
\end{tabular}

Note: Values are the mean of score given by 9 panels. Figure in the parentheses are the standard deviation. Values in the column bearing similar superscripts are not significantly different at $5 \%$ level of significance.

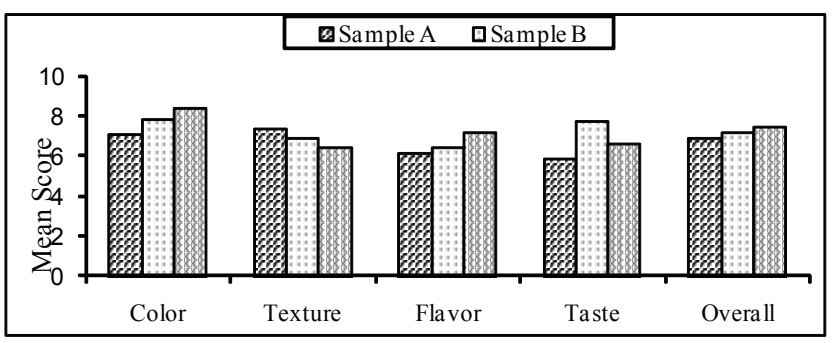

Figure 4. Effect of heating temperature of milk on the sensory attributes of soft cheese

The colour of the cheese sample was found to be white and shiny. The texture of cheese sample was soft and spoonable. However, sample A was slightly hard with good texture this might be due to lower moisture content of cheese where as in case of sample B and $\mathrm{C}$ moisture content was high to that of sample A so the texture was not firm, lacking definite body shape. Most of the panellists like the flavour of sample C. According to Bank (1990), pasteurization $\left(63^{\circ} \mathrm{C} / 30 \mathrm{~min}\right)$ is generally considered as the safest alternative, but the full flavour of traditional cheese cannot be achieved where as pasteurization at $90^{\circ} \mathrm{C}$ for $60 \mathrm{sec}$, process permits, fuller flavour of cheese with better control of culture growth (i.e. acid development) than with a raw milk. Taste of the sample B was found good as compared to sample A and C.

Both sample $\mathrm{B}$ and $\mathrm{C}$ were given the highest score and this might due to the flavour and taste produced by natural flora of milk. The sample A scored lowest, which might be due to decrease in flavour intensity during pasteurization of milk at high heated milk.

\section{Conclusion}

The optimum pasteurisation condition for preparation of goat cheese was $90^{\circ} \mathrm{C}$ for $60 \mathrm{sec}$. Pasteurization conditions affect the compositional characteristics, sensory qualities, and yields of cheese. At increasing temperatures, the level of moisture and yield increases significantly while the level of protein and fat in cheese decreases. Raising pasteurization temperature from $63^{\circ} \mathrm{C}$ for $30 \mathrm{~min}$ to $90^{\circ} \mathrm{C}$ for $60 \mathrm{sec}$ significantly reduced the firmness of cheese. Further investigation on shelf-life of soft goat cheese can be encouraged including hard type of cheese can also be prepared. Yield from the different breed can also be studied.

\section{References}

Abou-Donia S. A. (1986). Abou-Donia, Egyptian Domiati soft white pickled cheese. New Zealand J. of Dairy Sci. and Tech., 21:167-195.

Banks J. M. (1992). Cheese. In: The Technology of Dairy Products, Ed. R. Early, VHC Publisher, Inc. New York.

Callanan T. (1991). Recovery of milk constituents in cheesemaking. Factors Affecting the Yield of Cheese. IDF Special Issue No. 9301, Square Vergote, Brussels, Belgium.

DDC, (2005). Quality control handbook Dairy Development Corporation, Kathmandu, Nepal.

De S. (2004). Outline of Dairy Technology. Oxford University press, New Delhi, India.

Fox P. F. (1987). Cheese: an overview. In: Cheese: Chemistry, Physics and Microbiology, Vol (1), general aspect, Ed. P.F. Fox, Elsever Applied Science, London, pp.1.

Goat cheese nutrient. Avaailable at: http:/len.wikipedia.org/ wiki/Goat_milk_cheese (Accessed 24 May, 2009), Gosta Bylund (Ed.). 1995. Dairy processing handbook. Tetra Pak Processing System. AB.S-22186 Lund-Sweden.

Guinee T. P., Fenelon M. A, Mulholland E. O., O’Kennedy B. T., O'Brien N. and Revillle W. J., (1998). The influence of milk pasteurization temperature and $\mathrm{pH}$ at curd milking on the composition, texture and maturation of reduced fat cheddar cheese. International J. of Dairy Tech., 51: 1-10.

Harper W. J. and Kristooffersen T. (1967). General Technology of Cheese Manufacture. J. Dairy Sci. 10, 3092-3098.

K.C. Jagat and Rai B. K. (2007). Basic Food Analysis Handbook. (1 ${ }^{\text {st }}$ edn.) Prompt Printer Pvt. Ltd. Anamnagar, Kathmandu, Nepal. 
Kalantzopoulos G. C. (1993). Cheeses from ewes and goats milk. Chapter 16 In: Cheese: Chemistry, Physics and Microbiology. Vol. (2). Ed., P.F. Fox, Chapman and Hall, London.

Kosikowoski F. V. and Mistry V. V. (1995). Cheese and fermented milk foods. Volume-I, $3^{\text {rd }}$ edition 1999.

Kosikowoski F. V. and Mistry V. V. (1997a). Ultrafiltration in cheese making. In: Cheese and fermented milk foods, vol. I. Origins and principles, F.V. Kosikowski and V. V. Mistry, Editors, Kosikowski, F. V., L. L. C, Westport. CT, USA (1997).

Pradhan S. K. (2000). Effect of renneting temperature and $\mathrm{pH}$ on the fat, protein and total solid retention in cow milk cheese. B. Tech. Thesis. Tribhuvan University, Nepal.

Ranganna S. (2000). Handbook of Analysis and Quality Control for Fruits and Vegetable Products. Tata McGraw-
Hill Publishing Co. LTD.pp.1038-1040, 1052-1054.

Upadhaya K. G. (2003). Essential of chhesemaking. ${ }^{\text {st }}$ (Edn), Anand Press. Gujarat Agricultural University, Anand. Value for Human Nutrition. Available at: http://www. goatworld.com/articles/purpose/makingcheeseyoghurt. shtml (Accesed 18 Nov, 2010)

Wallace J. M and Fox P. F. (1997). Effect of adding free amino acid to cheddar cheese curd on proteolysis, flavour and texture development. Int. Dairy J., 7:157-167. 